\title{
THE TENDENCIES OF HARMONISED INDEX OF CONSUMER PRICES IN LITHUANIA AND EUROPEAN UNION
}

\author{
Ūla Urbaitè \\ Vilnius Gediminas Technical University \\ E-mail: ula.urbaite@vgtu.lt
}

\begin{abstract}
This article analyses the criterion of price stability, which plays an important role for Lithuanian ability to adopt the Euro. This work concentrates on analyses of price stability more deeply, presenting the methodologies of determination of inflation rate. The research is based on forecast of short and long-term tendencies of inflation rate in Lithuania and European Union in order to determine the future opportunities to meet price stability criterion and to adopt the Euro. Lithuanian Harmonised Index of Consumer Prices is forecasted for short and long-term, taking into account the present economical crises period and compared with predictions of other institutions such as Ministry of Finances, EC and SEB Bank.
\end{abstract}

Keywords: Harmonised Index of Consumer Prices, Consumer Price Index, COICOP, Maastricht criterion, the BalassaSamuelson effect.

\section{Introduction}

The absorption of the New Member States (NMS) after the 2004 enlargement and their integration into Economic and Monetary Union is one of the most important challenges facing the European Union (EU). Indeed, the NMS have declared that they want to join the monetary system as soon as feasible. The EU made a political decision on the first round of the implementation of the common currency, but this will not happen anymore. Lithuania had declared its will to join the Euro area at the beginning of 2007 , but this wish had been rejected on the grounds that consumer prices have overshot the strict inflation target.

Lithuanian failure to adopt the Euro from 2007 influenced many scientists to pay attention that there is not the same nature for nominal convergence criteria. Especially take into consideration previously not investigated problem: integration of different level economic countries. The present idea of inflation rate calculation based on arithmetic mean of the best three performing countries with the lowest inflation is the wrong assumption on price level stabilization in such circumstance when the lower economically developed countries are integrated. The evaluations of inflation rate methodology for lower economically developed countries ignore the fact that they are in real convergence process and seeking to reach the level of better-developed countries. What is more, only NMS inflation rate has price convergence component explained by Balassa-Samuelson effect.
The core target of this study is to estimate the forecast model for Lithuanian Harmonised Index of Consumer Prices (HICP). There is no doubt that the convergence criteria could be met by Lithuania, but the question is when Lithuania will be able to put its finances in order.

\section{Analysis of Price Stability Criterion in Lithuania}

Lithuanian case showed that the importance of careful practical preparations was particularly relevant since the country planned to introduce the Euro by "big bang" scenario in 2007 (Ciegis et al. 2008). While Slovenia has met the tough set of fiscal targets for the Euro membership, Lithuania has been rejected on the grounds that consumer prices in the small Baltic state have overshot the strict inflation target for nations seeking to join the Euro. The average annual inflation in Lithuania was slightly higher than the reference value established by the Maastricht Treaty. Therefore, in May 2006 the European Commission (EC) and the European Central Bank (ECB) concluded that price stability criterion was missed by only $0.1 \%$. Thus Lithuania missed historical opportunity to join the Euro area from January 2007. Figure 1 shows the evolution of average annual inflation in Lithuania measured by HICP for each month compared to required rate for Maastricht criterion in period 2007-2009. Lithuanian inflation rate was higher than the required Maastricht criterion in this period. For instance, Lithuanian HICP made up 11,1\% in December 2008 but required rate was 4,03\% in December 2008 . 


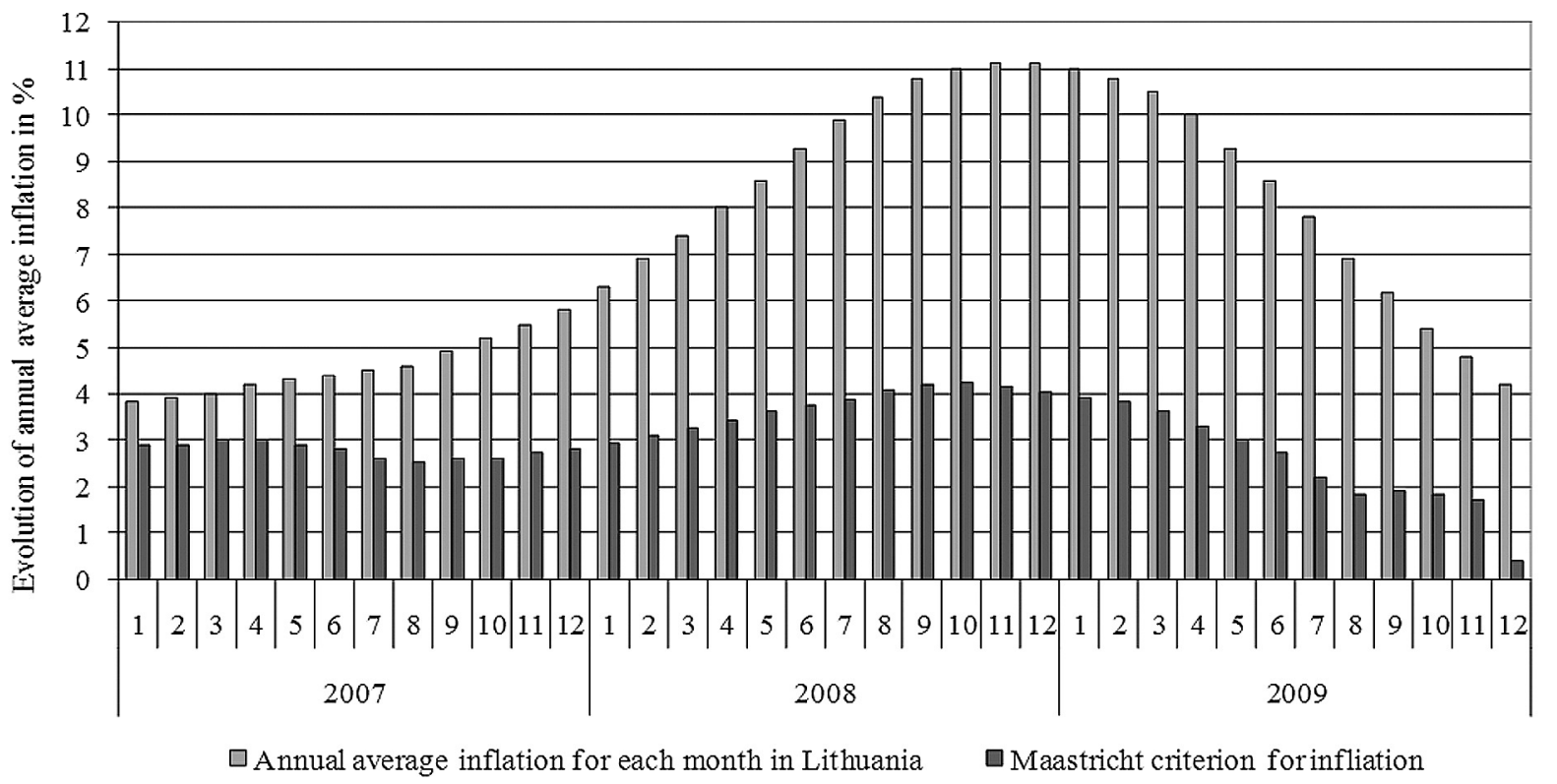

Fig. 1. Evolution of Average Annual Inflation and Maastricht Criterion

Scientists are paying attention that there is not the same nature for nominal convergence criteria and overlooking implementation problems for different economically developed countries. The calculations of Maastricht criterion for inflation and keeping on it strictly do not satisfy the real situation for different EU countries. The price level is becoming closer in integrated economies (Hsing, Sergi 2009). Due to integration process, less developed countries cannot avoid rapid inflation movements in comparison with average inflation of EU countries (Bukevičiūtè 2006).

The most important aspect of price increase in less developed countries is called Balassa-Samuelson (BS) effect. Only NMS inflation rate has price convergence component, explained by BS effect as well as sharp and rapid development of capital and labour movements. Price stability criterion for different economically developed countries joining Economic and Monetary union (EMU) should be established according this formula: the arithmetic mean of inflation rate in members of EMU plus value that shows calculated Balassa-Samuelson effect. According to the literature, the estimates of the BS effect in the Baltic States vary from zero to $2 \%$ per annum (Čičinskas 2009).

Lithuania has two solutions in order to fulfill Maastricht criterion for inflation. First option is to implement more elastic currency exchange rate system. $15 \%$ limits of currency exchange rate fluctuations can afford more freedom to act rather than $1,5 \%$ limit for seeking inflation rate. Second option for Lithuania is to use its fiscal policy in order to create recession. This could minimize inflation to required one. Furthermore, none of these alternatives are welcomed.

\section{Data and Methods Used}

Lithuanian HICP was predicted according to difficult economic circumstances and global recession nowadays. There was created an assumption for Lithuanian HICP calculations by individual items. Further research is concentrated in the determination of the Maastricht criterion for inflation and forecasted for all EU member states in short and long-term basis. The conclusions and opportunities to meet the Maastricht criterion for price stability are determined with reference to prognosis of EC, Ministry of Finances of Lithuania and SEB Bank. Different methodologies and estimations of inflation rate measured by HICP and CPI are explained as well.

The study was carried out in several stages:

- the forecast of annual average inflation rate in Lithuania and determined opportunities to meet the Maastricht criterion for inflation in the future;

- the short and long-term linear trend analysis;

- the long-term forecast of Lithuanian HICP calculated by individual items with 12 divisions.

There are many measures of inflation, depending on the basket of goods selected. Consumer Price Index (CPI) measures the price of selection of goods purchased by a 
"typical consumer" and "it reflects the changes in the price of a representative basket of goods and services sold in a country“ (Baily, Martin 1991; Khan 2006; Poindexter 1986). Goods and services are grouped by the COICOP classification with 12 divisions. COICOP stands for Classification of Individual Consumption by Purpose by United Nations statistical methodology (Gandolfo 2001). Twelve divisions of COICOP classification:

$-01-$ Food and non-alcoholic beverages,

$-02-$ Alcoholic beverages and tobacco,

-03 - Clothing and footwear,

- 04 - Housing, water, electricity, gas and other fuels,

-05 - Furnishings, household equipment and routine maintenance of the house,

- 06 - Health care,

-07 - Transport,

-08 - Communications,

$-09-$ Recreation and culture,

-10 - Education,

-11 - Hotels cafes and restaurants,

-12 - Miscellaneous goods and services.

The HICP may be described as a set of EU Consumer Price Indices calculated according to a harmonised approach. The HICP is an instrument used by the ECB to pursue monetary policy and monitor inflation in the EMU.

It is extremely important to distinguish between inflation based on CPI and HICP. For comparison to Maastricht criterion the later is used. The differences between HICP and individual national CPI can sometimes be significant in practice. The differences have been in general diminishing, although national CPI uses their own national methodologies. In many countries national CPI were set up to serve different purposes, for example as "cost of living indices" or "compensation indices". Some of the underlying concepts and methods of national CPI are inappropriate for the HICP as a "pure" inflation measure (of the impact of inflation on purchasing power).

Purpose: HICP is the instrument for measuring inflation in the EU and accomplishment of comparisons on the international scale. It is used for calculation of the European index of consumer prices (covers 27 EU Member States), the Monetary Union index of consumer prices (covers 16 participating countries of Economic and Monetary Union) and the European Economic Area index of consumer prices (covers 27 EU Member States, Iceland and Norway). The national CPI is used to measure the level of inflation in the country. It is the key instrument for indexation and compensation (Bikas 2008).

Coverage: HICP covers consumer expenditure met by residents of the country, institutional households, non- residents and visitors from abroad within the economic territory of the country. National CPI covers consumer expenditure met by residents of the country only. The HICP does not cover expenditure of households for gamble and financial intermediation services. The national CPI covers them.

Weights: due to a different coverage of consumption expenditure, weightings used for the HICP and CPI calculation slightly differ. This is the primary difference affecting the value of the index. The differences between weights (according to 12 divisions) used for calculation of HICP and CPI in 2009 are presented in the Figure 2.

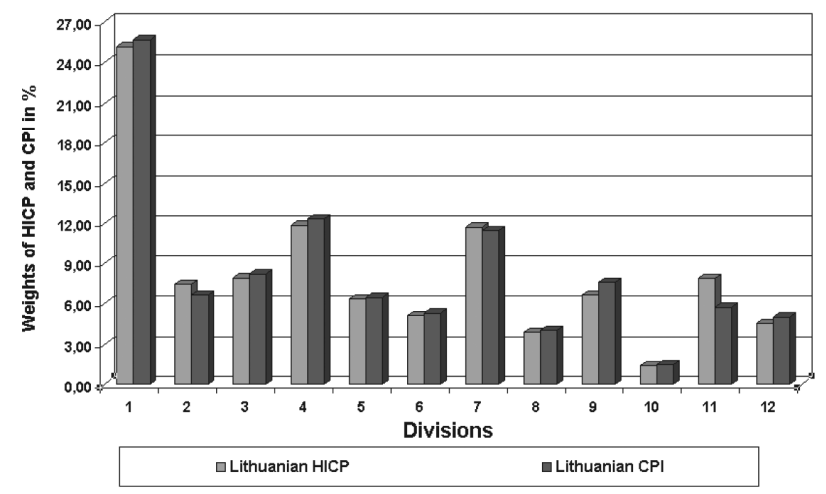

Fig. 2. Weights Used for CPI and HICP Calculations in 2009

Classification: to calculate the HICP classification COICOP/HICP adjusted to harmonised index is used. Classification COICOP is used to calculate national CPI. The main 12 divisions are quite the same for both methods. The differences between inflation rate in Lithuania measured by CPI and HICP in 2000-2009 years are shown below in Figure 3.

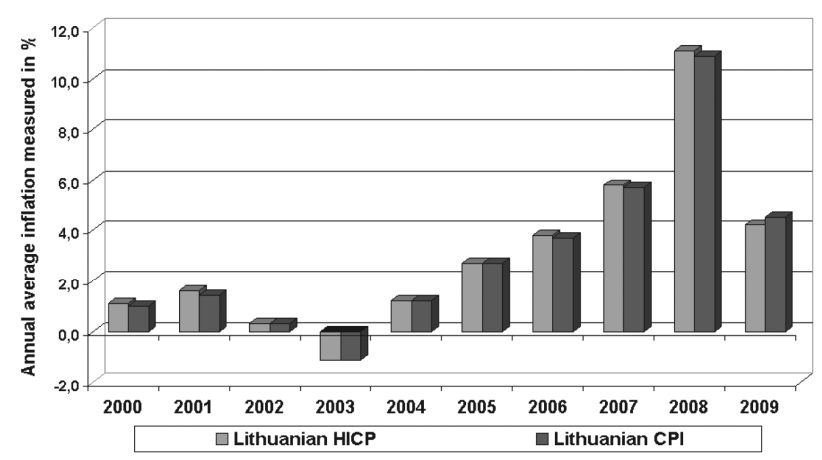

Fig. 3. Difference between Inflation Measured by CPI and HICP in Lithuania

Although there are differences between coverage of the both two indexes, the final indexes differ by small amount. Due to this, they should not be mixed or considered as the same. These indexes differ by purpose, coverage, weights and classification. 


\section{Dependence between Lithuanian HICP and Required Maastricht Criterion for Inflation}

The faster expansion of Lithuanian economy, conditioned by integration into EU, caused higher inflation in post integration period. Due to additional integration impulse on GDP growth the inflation was higher than required rate of Maastricht criterion. It should be noted that this increase is not only a specific effect of integration but a natural result of faster economic growth for Lithuania (Lakštutienè 2008).

There are various economic variables, which have an impact on consumer inflation in the short and medium run. For instance, credit growth, wage growth, productivity growth, the level of interest rates, administrative decisions, money growth and others. Particularly strong growth in the domestic demand compared to growth in net export in some NMS contributed to widening inflation gap versus the Euro area. It is relevant for Baltic States in particular, which experienced high inflation recently (Melnikas 2008). High domestic demand growth was mainly due to strong credit and wage growth and a steep increase in housing prices (Çelik, Özerkek 2009). Wage developments had a strong impact on inflation in the new EU member states. The Baltic States stand out as countries with the highest wage growth relative to labour productivity growth. From Figure 4 it is seen that Lithuanian HICP was lower than required rate of Maastricht criterion starting at 1999 and ending at 2004. One year before entering EMU, Lithuanian HICP started to increase.

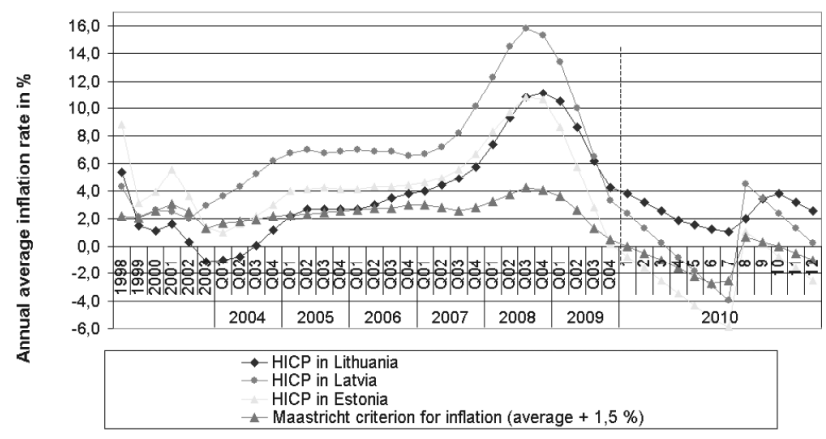

Fig. 4. HICP in Lithuania, Latvia, Estonia and Maastricht Criterion in 1998-2010

Reference month for convergence review was March of 2006 (see Figure 4). At that date annual average inflation in Lithuania was 2,7\% (Maastricht criterion was $2,6 \%$ ) being $0,1 \%$ above the reference value. The main argument was that the inflation rate in Lithuania has tendency to grow, and Lithuania has obligations to increase excises. The prices of oil have increased as well as other prices, which forced inflation rate to be high in 2006 and
2007. The historical data of Lithuanian HICP shows that the forecast made by EC was completely correct, taking into account too high inflation rate in Lithuania. What is more, the Maastricht criterion for inflation has been quite stable and fluctuated from $2,0 \%$ up to $4,1 \%$ in period 1998-2008.

In 2008, Lithuanian annual average HICP peaked at $11,1 \%$ compared with $5,8 \%$ in 2007 . External factors such as soaring energy and food prices considerably increased inflation in 2008. Domestic demand pressures contributed even more to price increases, as reflected in high wage growth. Inflation started to ease in the last quarter of 2008 and further decreased to $4,2 \%$ at the end of 2009. Rises in electricity and gas tariffs as well as increases in Value Added Tax (VAT) and a hike in excise duties temporarily pushed up inflation at the beginning of 2009. However, weak domestic demand and lower wages exerted a downward pressure on inflation and disinflation processes are set to continue in 2010 .

The economic downturn is likely to be accompanied by a sharp rise in unemployment to nearly $15 \%$ in 2009 2010. This should slow wage growth significantly, and had an impact of wage cuts in the public sector. After continuing excessive wage increases at the beginning of 2008 , wages started to adjust to the changing situation in the labor market (Martinkus et al. 2009). Given flexibility to Lithuanian labor market had an impact to average nominal wage growth. It is expected to turn strongly negative in the following years, helping to restore cost competitiveness by further substantial depreciations in the neighboring countries that are significant trading partners.

Lithuanian Government formed in December 2008 adopted a substantial fiscal consolidation package that included both wide-range tax changes and large expenditure restraint. On the revenue side, the main measures included increases in VAT and excise duties and a cut in personal income tax. The corporate income tax rate was raised and most tax exemptions removed, broadening the tax base (Tvaronavičienè et al. 2009). The budget also included major expenditure cuts by reducing public sector wages, investment and other current expenditure.

Tax revenues in the early months of 2009 dropped more substantially than expected. A further worsening macroeconomic outlook and much lower than budgeted tax revenue led the government to adopt a restrictive supplementary budget in April 2009, targeting a general government deficit remaining below 3\% of GDP in 2009. Despite these efforts, the general government deficit was widening to over 5\% of GDP in 2009 and it is rising significantly up to $9 \%$ in 2010 . 


\section{The Impact of Excises Duty to HICP in Lithuania}

Inflation was stimulated especially by changes of indirect taxes (VAT, excises) at the beginning of 2009. At $1^{\text {st }}$ of January 2009, Lithuanian Government increased excises of alcohol beverages and petrol. At $1^{\text {st }}$ of March in 2009, Lithuanian Government increased excises of cigarettes. VAT increased from $5 \%$ up to $19 \%$ at $1^{\text {st }}$ of July in 2009 for specific goods and services. In the long run, this situation will be different because economy slow down will affect the prices of consumption. Wage decrease and households tendency to have savings restricted purchasing power in the local market. Purchasing power of consumers decreased not only of economic slowdown and unemployment level incremental but also for additional VAT pressure.

There was made an assumption that the prices of food products and meal services will decrease $15 \%$ this year and further one. There was predicted that alcoholic beverages, tobacco and fuels for own cars will increase by $10 \%$ this year due to excises duty impact. Prices for clothes will decrease by $10-15 \%$ during the period of 2010 and 2011 , because of different habits of consumers nowadays. Prices for gas were decreasing in foreign markets due to this Parliament of Lithuania approved new legislation by which prices of hot water and heating will be recalculated each month. In 2010, the prices of hot water, heating and gas may increase again due to electricity price shock. Total increase in prices for these divisions will be $15 \%$.

Electricity price shock expected after the closure of the "Ignalina" nuclear power plant by the end of 2009 due to this it is assumed that in 2010 prices of electricity will increase $45 \%$. According these data, there were made the assumptions to sub-divisions in order properly forecast Lithuanian HICP by individual items.

The significant further increase of unemployment rate in Lithuania as well as decrease in gross earnings of employees will affect purchasing power of Lithuanian consumers (Tvaronavičius, Tvaronavičienè 2008). All these factors will have impact to Lithuanian HICP. A lot of depends on Lithuanian Government that has powerful tools to execute monopoly ventures in order to manage inflation rate to required one.

Table 1. Predicted Impact by Individual Items for Lithuanian HICP in 2010-2012

\begin{tabular}{|c|c|c|c|c|c|c|}
\hline Sub-division & Product & & 2009 & 2010 & 2011 & 2012 \\
\hline \multirow{3}{*}{011} & \multirow{3}{*}{ Food } & Price change & & $-15 \%$ & $-15 \%$ & - \\
\hline & & Weight (\%) & $23.07 \%$ & 23.07 & 23.07 & 23.07 \\
\hline & & Change in HICP (\%) & & -3.45 & -3.45 & 0.00 \\
\hline \multirow{3}{*}{021} & \multirow{3}{*}{ Alcoholic beverages } & Price change & & $10 \%$ & $10 \%$ & - \\
\hline & & Weight $(\%)$ & $4.88 \%$ & 4.88 & 4.88 & 4.88 \\
\hline & & Change in HICP (\%) & & 0.49 & 0.49 & 0.00 \\
\hline \multirow{3}{*}{022} & \multirow{3}{*}{ Tobacco } & Price change & & $10 \%$ & $10 \%$ & - \\
\hline & & Weight $(\%)$ & $2.91 \%$ & 2.91 & 2.91 & 2.91 \\
\hline & & Change in HICP (\%) & & 0.29 & 0.29 & 0.00 \\
\hline \multirow{3}{*}{0312} & \multirow{3}{*}{ Clothes } & Price change & & $-15 \%$ & $-10 \%$ & - \\
\hline & & Weight (\%) & $4.99 \%$ & 4.99 & 4.99 & 4.99 \\
\hline & & Change in HICP (\%) & & -0.75 & -0.50 & 0.00 \\
\hline \multirow{3}{*}{044} & \multirow{3}{*}{ Water } & Price change & & $15 \%$ & $15 \%$ & - \\
\hline & & Weight (\%) & $1.38 \%$ & 1.38 & 1.38 & 1.38 \\
\hline & & Change in HICP (\%) & & 0.21 & 0.21 & 0.00 \\
\hline \multirow{3}{*}{0451} & \multirow{3}{*}{ Electricity } & Price change & & $45 \%$ & $45 \%$ & - \\
\hline & & Weight $(\%)$ & $2.17 \%$ & 2.17 & 2.17 & 2.17 \\
\hline & & Change in HICP (\%) & & 0.98 & 0.98 & 0.00 \\
\hline \multirow{3}{*}{0452} & \multirow{3}{*}{ Gas } & Price change & & $15 \%$ & $15 \%$ & - \\
\hline & & Weight $(\%)$ & $1.18 \%$ & 1.18 & 1.18 & 1.18 \\
\hline & & Change in HICP (\%) & & 0.19 & 0.19 & 0.00 \\
\hline \multirow{3}{*}{0455} & \multirow{3}{*}{ Heating } & Price change & & $15 \%$ & $15 \%$ & - \\
\hline & & Weight (\%) & $4.14 \%$ & 4.14 & 4.14 & 4.14 \\
\hline & & Change in HICP (\%) & & 0.62 & 0.62 & 0.00 \\
\hline \multirow{3}{*}{0722} & \multirow{3}{*}{ Fuels for own cars } & Price change & & $10 \%$ & $10 \%$ & - \\
\hline & & Weight (\%) & $4.08 \%$ & 4.08 & 4.08 & 4.08 \\
\hline & & Change in HICP (\%) & & 0.41 & 0.41 & 0.00 \\
\hline \multirow{3}{*}{111} & \multirow{3}{*}{ Meal services } & Price change & & $-15 \%$ & $-15 \%$ & - \\
\hline & & Weight (\%) & $6.03 \%$ & 6.03 & 6.03 & 6.03 \\
\hline & & Change in HICP (\%) & & -0.90 & -0.90 & 0.00 \\
\hline \multicolumn{3}{|c|}{ Total decrease $(\%)$} & & -1.93 & -1.69 & 0.00 \\
\hline \multicolumn{3}{|c|}{ Forecast of HICP (\%) } & 4.2 & 2.27 & 0.98 & 0.98 \\
\hline
\end{tabular}




\section{Forecasted Lithuanian HICP and Maastricht Crite- rion for Inflation}

All forecasts made to Lithuanian HICP in period of 2010 and 2012 are presented in Figure 5. The results of linear trend is quite surprising because it is hard to expect that Lithuanian HICP will reach 6,7\% this year, but calculations suggest such a rate. Due to this, the calculated results of linear trend should be rejected, because it does not correspond to the real circumstances in this crisis period. Taking into account forecast of Lithuanian HICP by individual items, Lithuanian HICP significantly decreases from 2,27\% in 2010 to $0,98 \%$ in 2011 and 2012. Forecasts for Lithuanian HICP are compared with forecasts made by other institutions such as: Ministry of Finances, EC and SEB Bank.

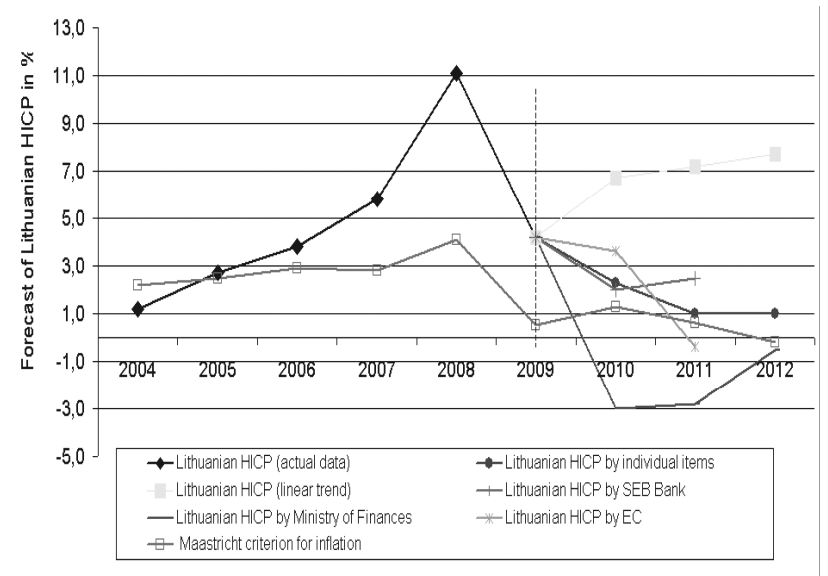

Fig. 5. Long-Term Forecast of Lithuanian HICP and Required Maastricht Criterion for Inflation

Figure 5 shows all made forecasts of Lithuanian HICP in period of 2010 and 2012. Taking into account data of EC and Ministry of Finances of Lithuania, the predictions differ too. There could be different rounding and different specific methods used and based on many other factors. EC forecasts that Lithuanian HICP will be 3,6\% but Ministry of Finances forecasts deflation of 3,0\% in 2010. Prognoses for further years differ too. The curve of Lithuanian HICP made by prognoses of individual items goes near to the line of Maastricht criterion at the end of 2010, but Lithuania will not fulfil Maastricht criterion for inflation in the near future. Linear trend forecast should be rejected because it does not correspond to the real situation of the economy of Lithuania.

The forecast of Maastricht criterion for inflation was done with a help of linear trend by using historical data from 1998 up to 2009 of all EA 16 countries and three other countries with strong economies such as UK, Den- mark and Sweden. The historical data showed that none of NMS had an impact to Maastricht criterion for inflation except Poland once in 2006 due to this the historical HICP of NMS was eliminated from Maastricht criterion predictions.

\section{Conclusions}

1. The present idea of inflation rate calculation is the wrong assumption on price level stabilization in such circumstance when less economically developed countries are integrated. Due to convergence process, less developed countries cannot avoid rapid inflation movements in comparison with average inflation of EU countries.

2. Price stability criterion should be calculated according this formula: the average of inflation rate in EMU countries plus value that shows calculated BalassaSamuelson effect.

3. It is extremely important to distinguish between inflation based on CPI and HICP. Later is used for comparison required Maastricht criterion.

4. Lithuania has two solutions in order to fulfil Maastricht criterion for inflation. First option is to implement more elastic currency exchange rate system. Second option for Lithuania could be to use its fiscal policy in order to create recession. Furthermore, none of these alternatives are welcomed.

5. The significant further increase of unemployment rate in Lithuania as well as decrease in gross earnings of employees will affect purchasing power of Lithuanian consumers. All these factors will have impact to Lithuanian HICP. A lot of depends on Lithuanian Government that has powerful tools to execute monopoly ventures.

6. Until the end of 2009, Lithuania had an obligation to increase excise duties on tobacco up to EU acquis minimal rate. Lithuania will face additional challenges related to the energy price shock after the closure of the "Ignalina" nuclear power plant. There was predicted $45 \%$ increase of electricity prices in 2010 . It is important to note, that VAT increased from $5 \%$ to $19 \%$ for specific goods and services by the end of 2009 .

7. The results of linear trend suggest that Lithuanian HICP will reach $6,7 \%$ in 2010 . Forecast of Lithuanian HICP by individual items, suggests significantly decreases from $2,27 \%$ in 2010 to $0,98 \%$ in $2011-2012$. Lithuanian HICP made by prognoses of individual items goes near to the line of Maastricht criterion at the end of 2010, but Lithuania will not fulfil Maastricht criterion for inflation in 2010-2012. 


\section{References}

Baily, J.; Martin, N. 1991. Macroeconomics, Financial Markets, and the International Sector. Homewood Boston: Irwin. 798 p.

Bikas, E. 2008. Lithuanian Household Savings Behaviour, Transformations in Business \& Economics 7(3): 154-169.

Bukevičiūte, L. 2006. On the Effects of Inter-Sector Productivity Growth Differences on Sectorial Inflation in the Baltic States Relative to the Euro Area, Ekonomika [Economics] 76: 7-16.

Çelik, S.; Özerkek, Y. 2009. Panel Cointegration Analysis of Consumer Confidence and Personal Consumption in the European Union, Journal of Business Economics and Management 10(2): 161-168. doi:10.3846/1611-1699.2009.10.161-168

Ciegis, R.; Jurgaityte, R.; Rakickas, A.; Kareivaite, R. 2008. The Analysis of Socio-Economic Progress and Future Perspectives in the New EU Members, Transformations in Business \& Economics 7(2): 34-54.

Čičinskas, J. 2009. Kainu stabilumo kriterijus stojančioje $i$ Pinigu Sajunga, kylančioje ekonomikoje: Lietuvos atvejis ir kitos pamokos [Price Stability Criterion Entering Economic and Monetary Union: Lithuanian Case and Other Lessons]. Vilnius: Tarptautinių santykiu ir politikos mokslų institutas. 13 p. (in Lithuanian).

EC. Annual Report 2009. European Commission for Economic and Financial Affairs [online], [accessed 5 January 2010]. Available from Internet:

$<$ http://ec.europa.eu/economy_finance/pdf/2009/interimfore castjanuary/2009 en.pdf $>$.

Eurostat databases 2009. [online], [accessed 19 January 2010]. Available from Internet:

$<$ http://epp.eurostat.ec.europa.eu/portal/page?_pageid $=1996$ $45323734 \&$ dad $=$ portal\& schema $=$ PORTAL\&screen $=$ welc omeef\&open $=/$ t_prc/t_prc_hicp\&language $=$ en\&product $=\mathrm{RE}$ F TB prices\&root $=$ REF TB prices\&scrollto $=0>$.

Gandolfo, G. 2001. International Finance and Open-Economy Macroeconomics. Berlin: Springer. 615 p.

Government of Lithuania 2009. Resolution for Convergence Programme [online], [accessed 20 January 2010]. Available from Internet:

$<\mathrm{http} / /$ www3.lrs.lt/pls/inter3/dokpaieska.showdoc_1?p id = $336024 \& p \_q u e r y=\& p \_t r 2>$.

HICP. Short Guide for users 2004. Harmonised Indices of Consumer Prices (HICP) [online], [accessed 8 January 2010]. Available from Internet:

$<$ http://epp.eurostat.cec.eu.int/cache/ity_offpub/ks-be-04001/en/ks-be-04-001-en.pdf $>$.

Hsing, Y.; Sergi, B. S. 2009. The Dollar/Euro Exchange Rate and a Comparison of Major Models, Journal of Business Economics and Management 10(3): 199-205. doi:10.3846/1611-1699.2009.10.199-205

Khan, M. 2006. Inflation and Financial Depth. Macroeconomic Dynamics. Boston: Irwin. 398 p.
Lakštutienè, A. 2008. Correlation of the Indicators of the Financial System and Gross Domestic Product in European Union Countries, Inzinerine Ekonomika - Engineering Economics (3): 7-18.

Maastricht Treaty 2006. Protocol on the Convergence Criteria [online], [accessed 15 January 2010]. Available from Internet:

$<$ http://www.hri.org/docs/Maastricht92/mt_protocols.html >.

Martinkus, B.; Stoškus, S.; Beržinskienè, D. 2009. Changes of Employment through the Segmentation of Labour Market in the Baltic States, Inzinerine Ekonomika - Engineering Economics (3): 41-48.

Melnikas, B. 2008. Integral Spaces in the European Union: Possible Trends of the Social, Economic and Technological Integration in the Baltic Region, Journal of Business Economics and Management 9(1): 65-77. doi:10.3846/1611-1699.2008.9.65-77

Poindexter, C. 1986. Macroeconomics. Illinois: The Dryden Press Hinsdal, 363-365.

Statistics Lithuania 2010. Department of Statistics to the Government of the Republic of Lithuania [online] [accessed 16 January 2010]. Available from Internet: $<$ http://www.stat.gov.lt/lt $>$.

Tvaronavičienè, M.; Grybaitè, V.; Tvaronavičienè, A. 2009. If Institutional Performance Matters: Development Comparisons of Lithuania, Latvia and Estonia, Journal of Business Economics and Management 10 (3): 271-278. doi:10.3846/1611-1699.2009.10.271-278

Tvaronavičius, V.; Tvaronavičienè, M. 2008. Role of Fixed Investments in Economic Growth of Country: Lithuania in European Context, Journal of Business Economics and Management 9(1): 57-64.

doi:10.3846/1611-1699.2008.9.57-64

\section{SUDERINTO VARTOTOJU KAINU INDEKSO TENDENCIJOS LIETUVOJE IR EUROPOS SĄJUNGOJE}

\section{Ū. Urbaitè}

Santrauka

Straipsnyje nagrinėjamas kainų stabilumo kriterijus, pabrèžiant skirtingus infliacijos rodiklio metodų skaičiavimus. Jis turi didžiulę itaką euro įvedimui Lietuvoje. Atliktas tyrimas remiasi trumpalaikemis bei ilgalaikemis infliacijos rodiklio tendencijų prognozemis Lietuvoje ir Europos Sajungoje, tam, kad būtu apibrèžtos Lietuvos galimybės atitikti Mastrichto kriterijų (kainų stabilumo) ir įsivesti vienodą Europos Sajungos valiutą ateityje.

Reikšminiai žodžiai: suderintas vartotojų kainų indeksas, vartotojų kainų indeksas, Mastrichto kriterijus, BalassaSamuelsono efektas. 